\title{
Financial Management and Performance of Selected SMEs: A Case of Kogi State - Nigeria
}

\author{
Yusufu Ojochenemi Sundaya ${ }^{*}$ \\ ${ }^{a}$ Kogi State University Anyigba - Nigeria
}

\section{A R T I C L E I N F O}

\section{Article history: \\ Received on: 05 January 2022 \\ Revised on: 13 January 2022 \\ Accepted on: 21 January 2022 \\ Published on: 03 February 2022}

\section{Keywords:}

Financial management

Financing

Investment decision

Performance of SMEs

\author{
A B S T R A C T
}

The study took a critical look at financial management and the performance of Small and Medium Enterprises in Kogi State Nigeria. The population of the study consist of 115 selected SMEs located in Lokoja metropolis in Kogi State Nigeria. Questionnaires were distributed to the operators of the sampled SME's. Multiple linear regression was adopted in analyzing the result. It was found that financing enhances the performance of small medium enterprises. The study also found that investment is significant to the performance of SME's, in Nigeria. The study concluded that the components of financial management is significant to the performance of small and medium enterprises. The study recommended that SME's should employ the services of portfolio managers that will help in investment decision making. Finally, there is need for SME's to increase their financial performance through effective long term plan.

Copyright ( $) 2021$ iRAPA International Journal of Business Studies. Published by International Research and Publishing Academy - Pakistan. This is an open access article licensed under CC BY: (https://creativecommons.org/licenses/by/4.0)

\section{Introduction}

Financial management is the act and science of managing money for effective utilization. Small and Medium Enterprises needs finance to meet business requirements in their day to day transactions (Cook \& Nixson, 2000). One of the sole rationale behind operating a business enterprise is to maximize profit, this is done through ensuring that funds are properly channeled to activity areas that leads to productive wealth creation in other to realize the overall objective of the enterprise. Financial management practices connotes analysis of investment of organizational funds in line with the best portfolio to general market valuation of the organization financial management strategy involves managerial controlling and planning of financial resources and activity of a firm to attain the overall objectives of the enterprise.
Small enterprises as engine of growth and developmental needs efficient financial management. It is widely believed that successful business cannot be under taken without sufficient capital. Most small businesses are eager to grow into large organization and even to multinational corporations but they often collapse even before the break even. Financial management is necessary to ensure not only the survival of SMEs but as a panacea for financial institutions to assist in the area of funding through proper financial record.

SME's are the propelling forces behind the success recorded in advance countries, example of such countries are USA, China, Taiwan etc. SMEs has really transformed the economies of developed countries by providing gainful employment and operating indigenous skills and idea recognition which has helped to develop manpower. Due to their numbers, size and grass roots- rural base, SME's are known to be the bedrock of rapid social and economic development (Etuk, Etuk \& Baghebo, 2014). In

\footnotetext{
Anyigba - Nigeria

E-mail addresses: sunnylivia42@gmail.com

DOI: https: / / doi.org/10.48112/iijbs.v2i1.115

Copyright (C) 2021 RAPA International Journal of Business Studies

Published by International Research and Publishing Academy

This is an open access article licensed under CC BY

(https://creativecommons.org/licenses/by/4.0)
}

* Corresponding author: Yusufu Ojochenemi Sundaya, Kogi State University

How to cite:

Sunday, Y. O. (2021). Financial Management and Performance of Selected SMEs: A Case of Kogi State - Nigeria. iRAPA International Journal of Business Studies, 2(1), 2226. https://doi.org/10.48112/iijbs.v2i1.115 
the developing economies, apart from lack of capital which is often ranked highest, they are often faced with problems of poor performance of SMEs which is necessitated by lack of financial management skills and strategy, wrong investment decision and poor financial reporting system leading to excessive take off cost among others (Shehu, 2014). Olajide, Tijani, Adeoye and Elegunde (2015) narrated that serious effort have been directed towards solving problem associated with incessant collapse of Small and Medium Enterprises. This financial skills needed for effective financial management ranges from good investment decision, proper cash management and financial reporting among others.

The broad objective of the study is to evaluate the effect of financial management and the performance of small and medium enterprises in Kogi State. Specific objectives are:

- To examine the influence of financing on the performance of SME's in Kogi State.

- To ascertain the effect of investment decision and the performance of SME's in Kogi State.

This section defines and explains key concepts as they relates to the subject matter, equally, the contextual structures of the work alongside relevant theories underpinning the study were discussed. Previous related studies were also reviewed in this section.

\section{Conceptualizing Financial management}

Kilonzo and Ouma (2015) define financial management as the management of funds and how this funds are channeled towards achieving the overall objectives of the organization and shareholders' value maximization. Kitonga (2013) observed that financial management in formal organizations include an accounting information system, capital structure management, working capital management, fixed assets management, financial reporting and analysis. Alhassan, Erasmus and Portia (2018) observed that financial management involves every aspects of management that affect the finances of the firms or company and what is required to achieve the overall objective of the organization. Karadag (2015) mentioned that requisite knowledge in financial management has a positive effect on the growth of small businesses. Shareholders' investment needed to be given good value, the maximization of shareholders wealth is paramount to the survival and growth of the firm (Yusufu, Suleiman \& Akuh,2020 ).

\section{Financing}

Financing involves the strategy which the firm adopts in mobilizing funds to meet the long term and short requirement of the firm. Long term sources of finance involves the mobilization of large funds with a repayable period of five years and above (Janse, 2020). Long term sources of finance is required to measure up with the capital expenses of companies which involves buying of assets, land ,building, plants and machineries. Mutua (2015) observed that short term sources of finance include funds obtain from the following sources, customer advances, trade credit, bank credit and money market instruments.

\section{Investment Decision}

Investing is one of the most crucial practices to achieve wealth and financial security which differs from trading. Gveroski and Jankuloska (2017) observed that funds for new investment can be realized from the sale of equity which is the initial invested assets of the owner and through raising of fund from financial institution or external sources.

Investment decision involves a long term process of selecting the best investment option and consider the suitable return from the investment. Capital budgeting techniques can be used to determine the effective utilization of an investment. An investment can be appraised using some of this capital budgeting techniques: net present value, accounting rate of return, internal rate of return, payback period etc.

\section{Concept of Small and Medium Enterprises}

It has been observed that SME's in Nigeria constitutes about $97 \%$ of the enterprises in the country, with a contribution of about $46 \%$ to the GDP and employing over $50 \%$ of Nigerian's labour force (MSME survey report , 2010; Taiwo, Ayodeji \& Yusuf, 2012). Small and Medium Enterprises are multiple and ranging from micro to cottage industries. SME's has potentials of generating employment at low capital cost. Small and medium enterprises can be viewed in relations to the value of assets available at its disposal. Several criteria are used throughout the world to describe small scale business, they are: Initial capital outlay, financial strength, relative size etc. For the context of this study, we shall adopt the Nigerian definition of SME.

A more proactive strategy is applied to address some major setback faced by SME's, these problems are poor access to finance, government frequent change of policies, multiple taxation and access to market. Performance of SME's can be measured in terms of size, profitability, growth in asset, competitive strength among others (Kaplan publishing, 2012).

\section{Empirical Review}

Muneer, Ahmed and Azhar (2017) studied the impact of financial management on small and medium enterprises with moderating role of agency cost. Primary data was obtained from two hundred SMEs from Faisalabad, Pakistan. The study adopted partial least square (PLS) to test the hypothesis. The study found a significant relationship between financial management and SMEs profitability. The study further recommends higher adherence to financial management.

Abimbola and Kolawole (2017) studied the effect of working capital management practices on the performance of small and medium scale enterprises (SMEs) in Oyo state, Nigeria. The study employed the use of primary data with a population of 150 SME's operators. The data was analyzed using multiple regression analysis and spearman rank correlation. Findings showed positive relationship between cash management and inventory management practices on the performance of SMEs. The study recommended that SMEs operators should take cognizance of working capital management in order to boost their performance.

Chinonye, Akinbode and Onochie (2015) examined the strategies for financing Small and Medium Enterprises in 
Nigeria: concepts and issues. The study used secondary data. Findings from the study revealed that several effort has been directed by both the government and international agencies in the area of financing SMEs.it was concluded that SMEs contribute to the national economy in the area of job creation, poverty alleviation, infrastructure provision and skill supply.

\section{Theoretical Review}

\section{Pecking Order Theory}

This study is anchored on pecking Order theory by Donalson in 1961 and modified by Stewart .C Meyers and Nicholas Majluf (1984). Pecking Order theory states that firms has a hierarchy for financing decisions. The best choice is to use internal financing before going for external funds. The Pecking Order Theory (POT) suggests that there is no well-defined optimal capital structure. The basis of Pecking order theory is that firms have no defined debt ratio. Management chooses to choose internal financing before external financing Internal funds bear no floating costs and do not require further disclosure of their own financial information, which could lead to a tougher marketing history and a possible loss of competitive advantage.

\section{Material \& Methods}

The study made use of survey method which was made possible through the use of questionnaire to obtain the data. The study population consist of 115 selected small medium enterprises within Lokoja metropolis using simple random sampling. Questionnaire were distributed to the sampled SME in order to elicit responses on their view based on the research question. In analyzing the data collected, the study used multiple regression.

\section{Specification of Model}

The model indicates the dependent variable which is performance of small medium enterprises (PSME). The model also specify the independent variable which is financial management (FMP). The model is presented thus:

$\mathrm{PSME}=\mathrm{f}(\mathrm{FMP})$

PSME $=\beta o+\beta 1$ FIG $+\beta 2$ IVD +

Where: $\mathrm{FMP}=$ an indicator representing financial management (Independent Variable);

Performance $\mathrm{SME}=$ Performance of small medium enterprises (dependent variable parameter)

$\beta o=a$ constant;

$\beta 1, \beta 2,=$ coefficient of the predictor variable;

$\mathrm{FIG}=$ Financing (predictor variable)

IVD= Investment decision (predictor variable)

$\mu=$ stochastic error term.

$\mathrm{f}=$ Functional relationship.

\section{Results \& Discussion}

Table 1

Model Summary

\begin{tabular}{lcccc}
\hline Model & R Square & Adjusted R Square & Std. Error & R Estimate \\
\hline 1 & .9277 a & 0.869 & 0.867 & 0.60276 \\
a. Predictors: (Constant), FIG, IVD & & \\
b. Dependent Variable: PSME & & & \\
\hline
\end{tabular}

Table 1 reveals that the adjusted $\mathrm{R} 2=.867$. The result indicates that about $92 \%$ relationship exist among the components of the independent variable and dependent variable. The $r$ Square value of 0.869 which indicates that the components of the predictor variable have a combined effect of $86 \%$ on the dependent variable. While the Adjusted r Square value of 0.867 also reveals that the accurate influence of the combined variables of financing and investment decision on the performance of small medium enterprises. About $86 \%$ of the variations in financial management are explained in the model, while $14 \%$ was not explained in the model.

Table 2

Anova Table

\begin{tabular}{l|lccccc}
\hline Model & Sum of Squares & Df & Mean Square & F & Sig. \\
\hline \multirow{3}{*}{1} & Regression 304.707 & 2 & 101.300 & 279.382 & $.000^{b}$ \\
\cline { 2 - 7 } & Residual & 41.158 & 115 & .362 & & \\
\cline { 2 - 7 } & Total & 346.767 & 118 & & & \\
\hline \multirow{2}{*}{ a. Dependent Variable: PSME } & & & & & &
\end{tabular}

a. Dependent Variable: PSME

Table 3

Coefficien

\begin{tabular}{|c|c|c|c|c|c|}
\hline Mode & & $\begin{array}{l}\text { unstandardized } \\
\text { Coefficients } \\
\text { B std .Error }\end{array}$ & $\begin{array}{r}\text { standardized } \\
\text { coefficients } \\
\text { Beta }\end{array}$ & s & $\mathrm{Sig}$ \\
\hline (constant) & 1.639 & .242 & & 6.762 & .000 \\
\hline FIG & .607 & .108 & 1.175 & 5.640 & .000 \\
\hline 1 IVD & .500 & .080 & .875 & 6.255 & .000 \\
\hline
\end{tabular}

\section{Findings}

The result of the T-Statistics value of 5.640 and the corresponding significant level of .000 indicating that financing is significant and has a positive relationship with the performance of small medium enterprises, base on this, the Null hypothesis (HO1) which says that financing does not have significant influence on the growth of small medium enterprises is rejected on the bases that the $\mathrm{p}$-value is less than 0.05. Finally, Table 3.2.2 above shows the result of T-statistics of 6.255 and the corresponding significant level of .000 which is significant at $5 \%$ which also indicates that investment decision is significant positively related with the performance of SME's, this indicates that the Null hypothesis (H02) that investment decision do not have significant effect on the performance of SME's, is rejected on the basis that the p-value is less than 0.05.

\section{Conclusion}

The study analyzed financial management on the performance of SME's, with the specific objective to ascertain the influence of investment decision and financing on SME's. Reviewed literatures focuses on the 
definition of financial management and its correlation on the performance $\mathrm{V}$.

The following recommendations were made:

(i) SME's, should employ the services of a portfolio manager that can help in investment decision making process.

(ii) Finally, there is need for Small and Medium Enterprises to increase their financial performance through effective long term plan, focusing on the strategic goals of the enterprise.

\section{References}

Abimbola, O.A., \& Kolawole, O. A. (2017). Effect of working capital management practices on the performance of Small and Medium Enterprises in Oyo state, Nigeria. Asian journal of economics, business and accounting. 3 (4): 1-8, article no.Ajeba.35237. ISSN: 2456639.

Abioro, M. (2013). The impact of cash management on the performance of manufacturing companies in Nigeria, uncertain supply chain management, 1 (3), pp. 177192.

Alhassan, M., Erasmus, D. G., \& Portia, P. (2018) Financial management, firm growth and Profitability of small and medium scale enterprises(SMEs).Information management and business review (ISSN 2220-3796) 10 (3), pp. 25-37.

Berger, A.N., \& Udell, G.F. (1998). The economics of small business finance: the roles of private equity and debt marketers in financial growth circle. Journal of banking and finance. 9 (22),873-897.

Biljon, V. (2015). SA SMEs struggle with cash flow as a result of delayed payment. Available at: http://www.businesspartners.co.za/mediaroom/press-releases/posts [Accessed 14 July 2020].

Chinonye, L.M., Akinbode, M.O., \& Onochie, M.P. (2015) Strategies for financing Small and Medium Enterprises in Nigeria: concept and issues. International journal of business and general management (IJBGM) ISSN (P):2319-2267;ISSN (E):2319-227, 4(5), 25-38 IASET .

Cook, P., \& Nixson, F. (2000) Finance and small and medium-sized enterprise development. Pearson education.

Enow, S. (2015). The working capital management practices of small medium and micro enterprises in the Cape Metropolis. Unpublished master of technology thesis. cape town. cape peninsula university of technology. Merchant factors. Finance beyond the numbers. available at: http://www.mfactors.co.za/articles .php\#2 [Accessed 14 July 2020]

Etuk,R.U., Etuk, G.R., \& Baghebo,M.(2014). Small and medium scale enterprises(SME's) and Nigeria's economic development. Mediterranean journal of social sciences, 5(7), 656-662.

Forkuoh, S. K. \& Li, Y. (2015). Electricity power insecurity and SMEs growth: a case study of the cold store operators in the as a market area of the Kumasi metro in Ghana. Open Journal of Business and Management, 3(03), 312.

Gveroski, T., \& Jankuloska, A.R. (2017) Determinant of investment decisions in SME's. Balkan and near eastern journal of social sciences ,03 (01).
Gyebi, F., Quain, S. (2013). Internal Control on cash collection.A case of the electricity company of Ghana 1td, Accra East region, International Journal of Business and Social Science, 4 (9), 217-233

Janse, B. (2020) Financial forecasting. Retrieved 8-072020 from toolshero: https://www.toolshero.com/financial- management /financial-forcasting.

Johnson, G., Scholes, K., \& Whittington, R. (2006). Exploring corporate strategy, Harlow, FT/ Pretence Hall.

Karadag, H. (2015). Financial management challenges in small and medium sized enterprises: A strategic management approach. Emerging markets Journal, 5, 26-40. Doi: 10.5195/emaj.67.

Kaplan Publishing. (2012). Kaplan Financial Knowledge Bank. Available at: http:/ / kfknowledgebank.kaplan.co.uk/KFKB/Wiki\%2 OPages / NonFinancial\%20Performance\%20Indicators $\%$ $20 \% 2$ 8NFPIs\%29.aspx. Accessed on 12 July 2020

Kilonzo J. M. \& Ouma. (2015). Financial management on the growth of Small and Medium Enterprises: A case of manufacturing enterprises in Nairobi County, Kenya. IOSR Journal of Business and Management, 17(8), 65-77. DOI: $10.9790 / 487 X-17826577$

Kitonga, K. G. (2013). The relationship between financial management and financial performance in the shipping industry in Kenya. Unpublished MBA project University of Nairobi, Kenya.

Muneer, S., Ahmad, R.A., \& Azhar, A. (2017). Impact of financial management on SMEs profitability with moderating role of agency cost. Information management and business review journal (ISSN 22203796) 9 (1), 23- 30.

Mutua, J. M. (2015). Effect of bookkeeping on the growth of Small and Medium Enterprises in Chuka town. European Journal of Business and Social Sciences, 4(7), 102-112.

MSMEs Survey Report (2010). A collaborative report on micro, Small and Medium Enterprises (MSMEs) in Nigeria, by national bureau of statistics (NBS) and small and medium enterprises development agency of Nigeria (SMEDAN).

Myers, S., Majluf, N, (21984). Corporate financing and investment decisions when firms have information that investors do not have. Journal of financial economics 13, 187-222.

Olajide, O., T., Tijani, A.A., Adeoye, A.O., \& Elegunde, A.F. (2015). Financial management as a tool for the growth of small business enterprises in Lagos State: An Empirical Approach. Indian Journal of Commerce \& Management Studies. ISSN2240 0310.EISSN:2229$5674 \mathrm{VI}(1)$

Rugui, L., \& Omagwa, J. (2018). Effect of financial management on performances of selected Small and Medium Enterprises in Limurutown, Kenya. International journal of scientific and education research .2. (05).

Shehu, A.M.(2014). Market orientation, knowledge management, entrepreneurial orientationand performance of Nigerian SME's. Ph.D Dissertation, university of utara, Malaysia.

Shina, A. (2017). Review study of strategic financial management from the perspective of organizational performance. International journal of information movement. ISSN:24560553, 2(V) 126-129.

Tabol, S. E., \& Kamala, P. (2016) Cash management practices of small, medium and micro enterprises in the Cape Metropolis, South Africa. Investment 
management and financial innovations.13 (1)230. DOI:10.21511/imfi.13 (1-1).10

Taiwo, A., Ayodeji,A.M., \& Yusuf , A.B. (2012). Impact of Small and Medium Enterprises on economic growth and development. American journal of business and management, $1(1), 18-22$.

Uwonda, G., Okello, N., Okello, N.G. (2013). Cash flow management utilization by Small Medium Enterprises (SMEs) in Northern Uganda, Merit Research Journal of Accounting, Auditing, Economics and Finance, 1 (5), 67-80.

Yusufu, O.S., Suleiman ,O. \& Akuh, J.I. (2020). Financial management strategy and the growth of small and medium enterprises. Ilorin Journal of Human Resource Management (IJHRM) .4,(2). 